\title{
A long-lived Late Cretaceous-early Eocene extensional province in Anatolia? Structural evidence from the Ivriz Detachment, southern central Turkey
}

\author{
Derya Gürer $^{\mathrm{a}, *}$, Alexis Plunder ${ }^{\mathrm{a}}$, Frederik Kirst ${ }^{\mathrm{b}}$, Fernando Corfu ${ }^{\mathrm{c}}$, Stefan M. Schmid ${ }^{\mathrm{d}}$, \\ Douwe J.J. van Hinsbergen ${ }^{\mathrm{a}}$ \\ a Department of Earth Sciences, University of Utrecht, Utrecht, The Netherlands \\ b Steinmann-Institute, University of Bonn, Bonn, Germany \\ c Department of Geosciences \& Centre for Earth Evolution and Dynamics, University of Oslo, Norway \\ d Institute of Geophysics, ETH Zurich, Zürich, Switzerland
}

\section{A R T I C L E I N F O}

\section{Article history:}

Received 24 February 2017

Received in revised form 25 September 2017

Accepted 5 October 2017

Available online 23 October 2017

Editor: R. Bendick

\section{Keywords:}

detachment

HP rock exhumation

extension

rollback

Eastern Mediterranean tectonics

slab segmentation

\begin{abstract}
A B S T R A C T
Central Anatolia exposes previously buried and metamorphosed, continent-derived rocks - the Kurşehir and Afyon zones - now covering an area of $\sim 300 \times 400 \mathrm{~km}$. So far, the exhumation history of these rocks has been poorly constrained. We show for the first time that the major, $>120 \mathrm{~km}$ long, top-NE 'Ivriz' Detachment controlled the exhumation of the HP/LT metamorphic Afyon Zone in southern Central Anatolia. We date its activity at between the latest Cretaceous and early Eocene times. Combined with previously documented isolated extensional detachments found in the Kırşehir Block, our results suggest that a major province governed by extensional exhumation was active throughout Central Anatolia between $\sim 80$ and $\sim 48 \mathrm{Ma}$. Although similar in dimension to the Aegean extensional province to the east, the Central Anatolian extensional province is considerably older and was controlled by a different extension direction. From this, we infer that the African slab(s) that subducted below Anatolia must have rolled back relative to the Aegean slab since at least the latest Cretaceous, suggesting that these regions were underlain by a segmented slab. Whether or not these early segments already corresponded to the modern Aegean, Antalya, and Cyprus slab segments remains open for debate, but slab segmentation must have occurred much earlier than previously thought.
\end{abstract}

(C) 2017 Elsevier B.V. All rights reserved.

\section{Introduction}

The tectonic evolution of the Mediterranean region is dominated by accretion of tectonic slices detached from subducted oceanic and particularly continental lithosphere. These accreted units were tectonically buried, often metamorphosed, and incorporated into thick nappe stacks that underwent subsequent extension, crustal thinning, and exhumation (e.g., Faccenna et al., 2014). Metamorphic rocks, mostly of high-pressure/low-temperature (HP/LT), subduction-related metamorphic facies, but also local HT/LP units, are common in the internal zones of the Mediterranean orogenic belts (Faccenna et al., 2014; Jolivet et al., 2003).

The exhumation of such subducted material back to the surface is often linked to overriding plate extension (Jolivet et al., 2013). The timing and style of these processes reflect major changes in

\footnotetext{
* Corresponding author.

E-mail address: derya.guerer@gmail.com (D. Gürer).
}

subduction zone dynamics and are keys to deciphering the motion history between the subducted slab and the overlying orogen. Exhumation in an overall convergent system is attributed to slab retreat relative to the overriding plate, creating the space needed for exhumation of HP-metamorphic rocks in subduction channels (Jolivet et al., 2003). Slab retreat also generates upper plate extension and development backarc (and forearc) basins, and can therefore trigger and assist exhumation of deeply buried portions of the orogen to the surface (Jolivet et al., 2003; Royden, 1993).

In the Mediterranean, metamorphic provinces occur associated with deep extensional and even oceanic basins, formed since the late Eocene-Oligocene and dominantly in the Miocene in the Alboran region, the Tyrrhenian Sea, the Pannonian Basin, and the Aegean region. In the latter, substantial volumes of metamorphosed rocks were exhumed extensionally (Faccenna et al., 2014; Jolivet et al., 2003; Rosenbaum and Lister, 2004; van Hinsbergen et al., 2010; van Hinsbergen and Schmid, 2012).

In Central Anatolia exhumed metamorphic rocks of the HP/LT Afyon Zone and the HT/LP Kırşehir Block (Fig. 1) are exposed in an 

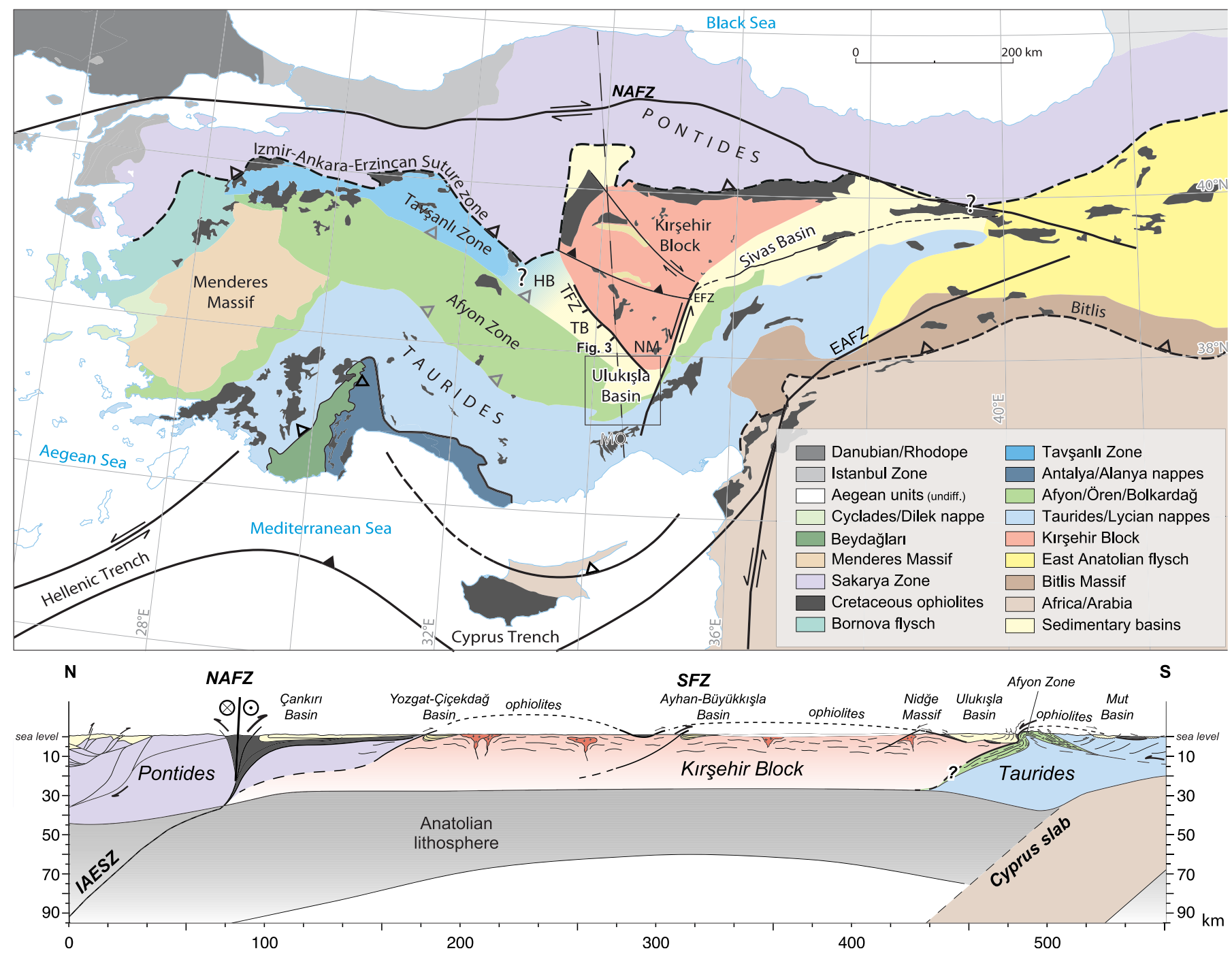

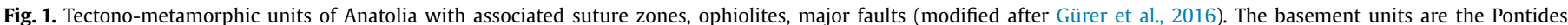

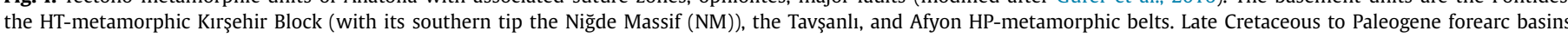

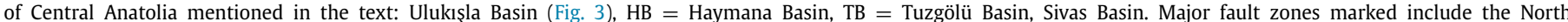

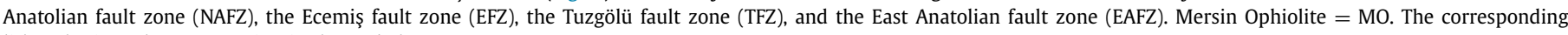
lithospheric scale cross-section is shown below.

area of $\sim 300 \times 400 \mathrm{~km}$. The size is comparable to the Mediterranean provinces, but in Central Anatolia exhumation occurred much earlier, in the Cretaceous to Paleogene. Although recent studies have identified isolated occurrences of extensional detachments that aided the exhumation of the Kırşehir Block (Gautier et al., 2002; Lefebvre et al., 2011), it was unclear how exhumation was accommodated in case of the Afyon Zone, which can be traced from western to central Turkey over a distance of $\sim 800 \mathrm{~km}$, fringing the Kırşehir Block in the south (Figs. 1, 2).

The Afyon Zone is in contact with a non-metamorphic ophiolite and ophiolitic mélange sequence, as well as sediments of the overlying Ulukışla Basin (Fig. 3). The latter formed during latest Cretaceous to late Paleocene extension in a forearc to arc setting (Gürer et al., 2016). Here we describe lithologies and structures along contacts between the Afyon Zone and the ophiolitic mélange around Ivriz (Fig. 3). Along- and across-strike kinematic field and thin-section analyses document the role of this structure for the exhumation of the Afyon Zone and $\mathrm{U} / \mathrm{Pb}$ ages constrain the timing of syn-kinematic granites. We discuss the implications of our findings in terms of direction and timing of regional extension and their profound consequences for the dynamics of eastern Mediterranean subduction evolution since the late Mesozoic.

\section{Geological setting}

\subsection{Central Anatolian geology}

Anatolia (Fig. 1) exposes an orogenic collage of rocks derived from continental and oceanic lithosphere that amalgamated since Mesozoic time during the closure of strands of the Neotethys Ocean. The northern part of the orogen is formed by the Pontides, which have been part of the southern Eurasian margin since at least the Mid-Mesozoic. The southern border of the Pontides, the Izmir-Ankara-Erzincan suture zone, demarcates the location of oceanic subduction since Jurassic time (Dokuz et al., 2017; and references therein; Fig. 1). To the south of this suture zone, there are the continent-derived, exhumed metamorphic rocks of the Kirsehir Block and the Afyon Zone. The latter overthrusted the external, Paleogene, E-W-trending thin-skinned Taurides fold-and-thrust belt (Özgül, 1984). All these elements are structurally overlain by isolated klippen of ophiolites and their underlying ophiolitic mélange (Fig. 1; Menant et al., 2016; van Hinsbergen et al., 2016). These ophiolites are interpreted to have formed above a second, intraoceanic subduction zone within the Neotethys located south of the Pontide subduction zone. The oceanic lithosphere intervening be- 


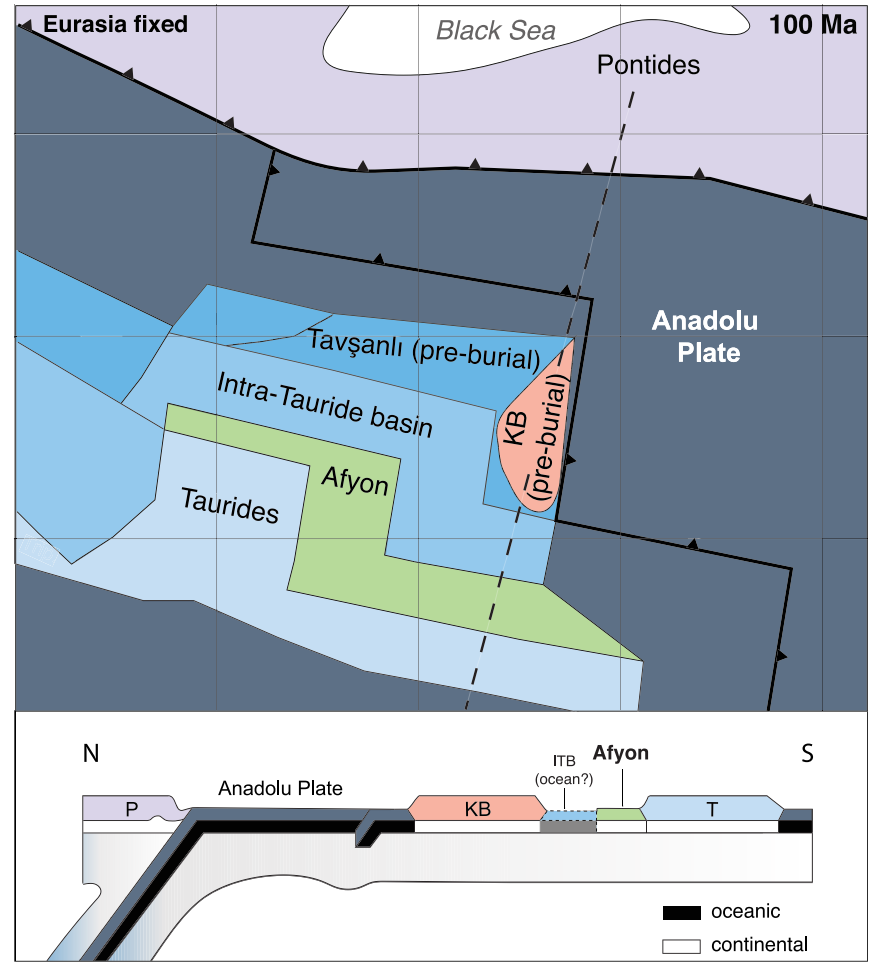

Fig. 2. Schematic paleogeography and plate boundary configuration of Central Anatolia at $\sim 100 \mathrm{Ma}$. Paleogeography of the Aegean and west Anatolian region are based on the reconstruction of van Hinsbergen et al. (2016) and van Hinsbergen and Schmid (2012); and on Gürer et al. (2016) in Central Anatolia. Lithosphericscale cross section (location indicated by dashed black line) is drawn for a time slice shortly after subduction initiation within the Anadolu Plate oceanic domain. Abbreviations used are as follows: $\mathrm{KB}=$ Kırşehir Block, $\mathrm{P}=$ Pontides, $\mathrm{T}=$ Taurides, ITB = Intra-Tauride basin

tween the two subduction systems is termed the 'Anadolu Plate' (Gürer et al., 2016). Tectonic reconstructions suggest that the intraoceanic subduction zone within this domain had a kinked geometry (in map view) following the former passive margin (see Gürer et al., 2016; van Hinsbergen et al., 2016; Fig. 2).

The Kırşehir Block consists of Paleozoic to Mesozoic metasedimentary rocks, which underwent HT/LP metamorphism under conditions estimated at up to $800^{\circ} \mathrm{C} / 8 \mathrm{kbar}$ at $\sim 85-90 \mathrm{Ma}(\mathrm{U} / \mathrm{Pb}$ on metamorphic zircon and monazite; Whitney and Hamilton, 2004; and references therein) following underthrusting of the Kırşehir Block below oceanic lithosphere (van Hinsbergen et al., 2016; and references therein). Structural analysis of the Kırşehir Block identified several extensional detachments (Gautier et al., 2002; Lefebvre et al., 2011) and retrograde extensional shear zones (Isik et al., 2008). When corrected for Cenozoic vertical axis rotations obtained from granitoids postdating metamorphism (Lefebvre et al., 2013), these data show that extensional exhumation occurred under $\sim$ E-W-directed extension since at least $\sim 80-75 \mathrm{Ma}$. Associated sedimentary basins suggest that E-W-directed extension had ceased by early Eocene time (Gürer et al., 2016; Isik et al., 2014 2008). The Kırşehir Block is presently bound by the major Tuzgölü and Ecemiş fault zones in the west and in the east, respectively (Fig. 1). Paleogeographically the Kirşehir Block probably represents the northern extension of the Taurides and is connected to the Tavşanlı Zone of western Turkey (Fig. 2; Poisson et al., 1996), that also comprises continental rocks. These were, however, metamorphosed under HP/LT metamorphic conditions (Plunder et al., 2015 and references therein) at $\sim 81-88 \mathrm{Ma}$ (Seaton et al., 2009) during underthrusting below oceanic lithosphere. There are no exposures of rocks of the lithosphere that subducted between $\sim 85 \mathrm{Ma}$, the accretion of the Kırşehir Block to the overriding oceanic litho- sphere, and $\sim 70-65 \mathrm{Ma}$, the accretion of the Afyon Zone (see below). This lithosphere is interpreted to have underlain a conceptual, possibly oceanic intra-Tauride basin (Gürer et al., 2016; van Hinsbergen et al., 2016 and references therein; Fig. 2).

The Afyon Zone is interpreted as the metamorphosed passive margin of the Tauride platform (Candan et al., 2005; Okay, 1986, 1984) and is located south of, and structurally below the Tavşanlı Zone and the Kırşehir Block (Fig. 1). The Afyon Zone contains a coherent stratigraphic sequence of Pan-African basement unconformably covered by a Paleozoic continental clastic sequence. This is, in turn, overlain by alkaline volcanic rocks (zircon U/Pb age of $229 \pm 2$ Ma; Özdamar et al., 2013) and unconformably covered by Early Triassic clastic sediments grading into an Late Triassic to Cretaceous carbonate platform sequence (Okay, 1984) and Maastrichtian continental clastics (Göncüoglu et al., 1992). Incipient blueschist-facies conditions have been reported both in glaucophane-bearing Pan-African metagabbro and in its sedimentary cover (Fe-Mg carpholite-bearing rocks). The pressure-temperature conditions were estimated at $10 \mathrm{kbar} / 375^{\circ} \mathrm{C}$ (Pourteau et al., 2014). Retrograde phengite ${ }^{40} \mathrm{Ar} /{ }^{39} \mathrm{Ar}$ growth ages of 67-62 Ma indicate that the Afyon Zone was being exhumed at this time (Özdamar et al., 2013; Pourteau et al., 2013). In western Anatolia, the Afyon Zone is unconformably overlain by late Paleocene-early Eocene shallow marine sedimentary rocks (Candan et al., 2005).

\subsection{Geology of the study area}

Along the northern margin of the Bolkar mountain range the Afyon Zone is juxtaposed against and dips below ophiolites and underlying ophiolitic mélange, which are unconformably covered by sediments of the Ulukışla Basin (Fig. 3). The ophiolites are strongly dismembered and preserved as klippen. The Alihoca Ophiolite to the north of the eastern Bolkar mountains and below the Ulukışla Basin has a supra-subduction zone (SSZ) geochemical affinity (Dilek et al., 1999), with gabbro that yielded a zircon $\mathrm{U} / \mathrm{Pb}$ age of $\sim 92 \mathrm{Ma}$ (Gürer et al., 2016). To the south, on top of the Bolkar mountains, the Kizlltepe Ophiolite is underlain by a metamorphic sole that yielded $\sim 91 \mathrm{Ma}{ }^{40} \mathrm{Ar} /{ }^{39} \mathrm{Ar}$ hornblende cooling ages (Dilek et al., 1999; Fig. 3). Finally, even farther to the south, overlying the non-metamorphosed Taurides, lies the extensive Mersin Ophiolite with similar crustal and metamorphic sole ages (Fig. 1; see review in van Hinsbergen et al., 2016).

In the Taurides the ophiolite and ophiolitic mélange are collectively referred to as the Bozkır Unit (Okay, 1986; Özgül, 1984). Kilometer-size Triassic to Late Cretaceous, non-metamorphic limestone blocks within the ophiolitic mélange are derived from the crust north of the Tauride platform and accreted to the mélange during underthrusting below the ophiolites, before the underthrusting of the Afyon Zone.

In the study area, blueschist-facies metamorphism in the Afyon Zone is attested by glaucophane-epidote-bearing metabasite embedded in the marbles (Blumenthal, 1956; our own observations), but no precise P-T estimates are available. In the northeastern part of the Bolkar mountains, the Afyon Zone is intruded by the Horoz granite with $\mathrm{U} / \mathrm{Pb}$ crystallization ages of zircon ranging from $\sim 50$ Ma (Parlak et al., 2013) to 56.1 Ma age (unpublished age quoted in Kadioglu and Dilek, 2010).

The latest Cretaceous stratigraphic units of the Ulukışla Basin unconformably overlies the Alihoca ophiolite and ophiolitic mélange. Eocene and younger rocks of the basin also unconformably cover the metamorphic units of the Kurşehir Block to the north, as well as the Afyon Zone to the south (Fig. 3). The basal stratigraphy of the basin records a first phase of uplift of the Alihoca ophiolite before $\sim 75$ Ma (Gürer et al., 2016). Subsequently, the basin became deep marine again at $\sim 75 \mathrm{Ma}$. Renewed 


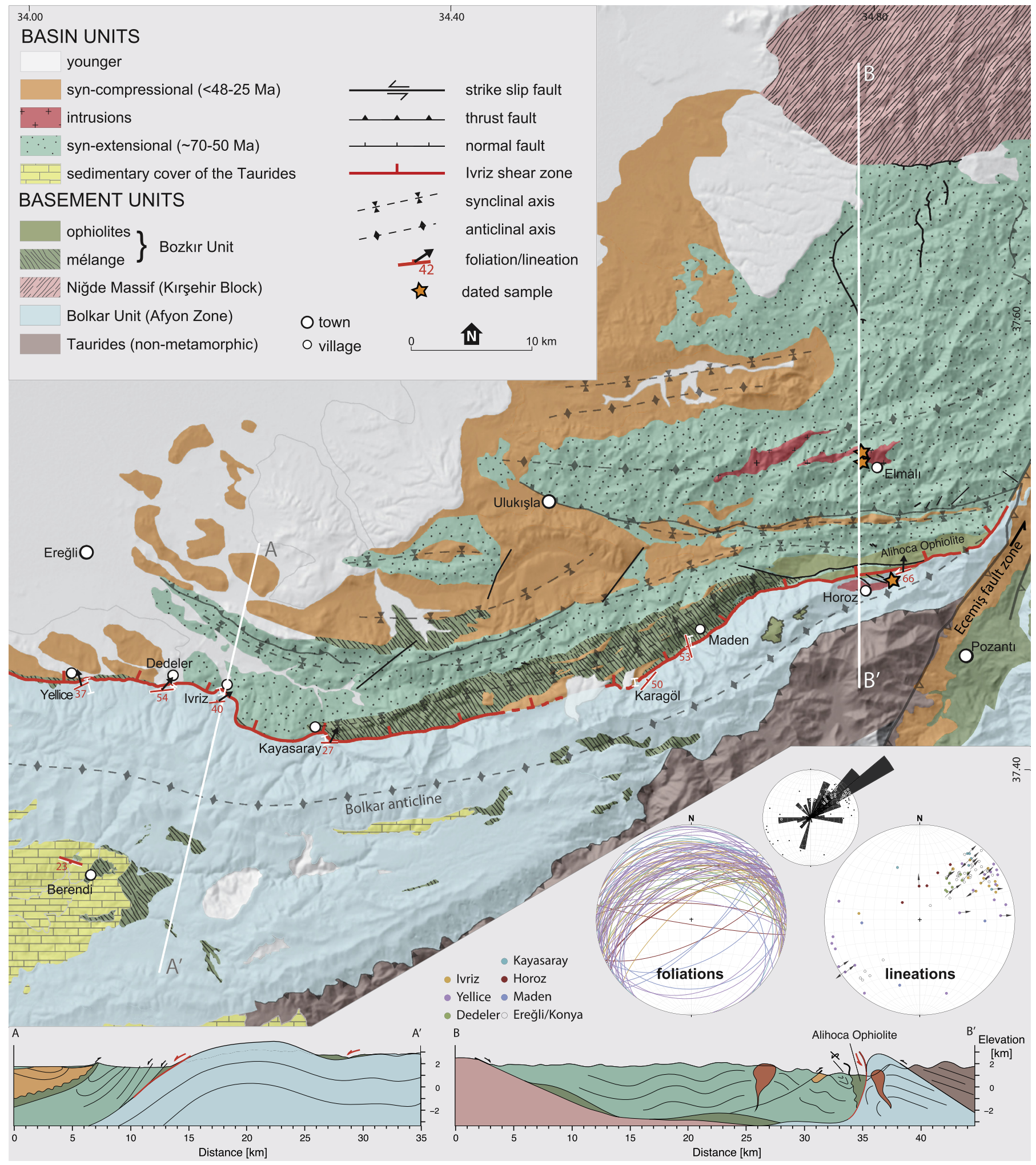

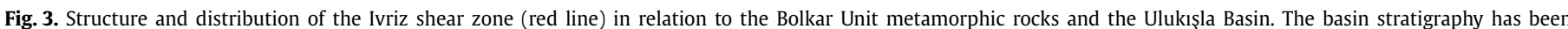

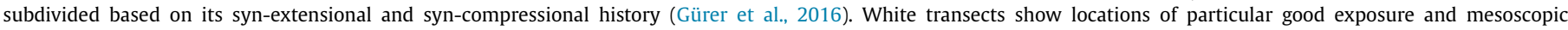

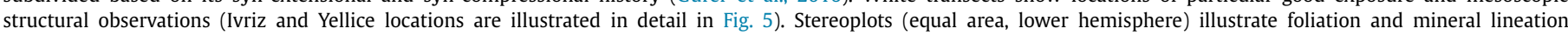

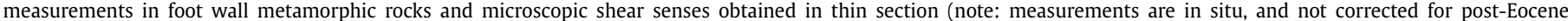

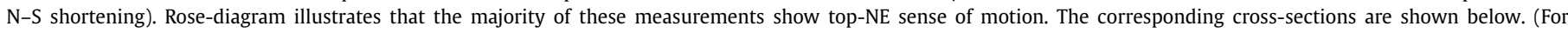
interpretation of the references to color in this figure, the reader is referred to the web version of this article.)

uplift took place before 65 Ma followed by subsidence and associated $\sim \mathrm{N}-\mathrm{S}$ and $\sim \mathrm{E}-\mathrm{W}$ extension from $\sim 65$ to 56 Ma leading to basin formation. Constraints for the timing and direction of extension are based on the kinematic analysis of numerous small offset normal faults with dip-slip kinematics, frequently associated with syn-kinematic sedimentation and/or variations in the sedimentary facies indicative of overall deepening. The $\sim \mathrm{N}-\mathrm{S}$ extensional phase affected the basal part of the stratigraphy (syn-extensional 
strata in Fig. 3). This phase of extensional basin formation was further associated with the exhumation of HP-metamorphic rocks contained in the basal coarse conglomerates of the Halkapinar Formation. These observations led Gürer et al., 2016 to infer that a large-scale, now overturned normal fault bounds the basin to the south. In Eo-Oligocene times, after this extension, the southern part of the basin, as well as the main basin-bounding normal faults became steeply tilted northward into a vertical limb of the south-verging Bolkar Fold Fig. 4a, c). As a result, the original normal faults are now in a thrust-fault geometry (Gürer et al., 2016; Fig. 3). A pronounced intensification of folding occurs from west to east (Fig. 4a), where the Bolkar Fold is cut by the major left-lateral Ecemiş fault zone (Fig. 3) that formed during the late stages of the Bolkar-folding (Gürer et al., 2016; Jaffey and Robertson, 2001).

\section{Results}

\subsection{Structural observations}

Along the entire southern margin of the Ulukışla Basin, a semilinear E-W trending tectonic contact separates the HP/LT metamorphic rocks of the Afyon Zone (Fig. 3) in the foot wall from ophiolites and the ophiolitic mélange in the hanging wall (Fig. 4b). This contact can be traced intermittently over a distance of $>120 \mathrm{~km}$ along the northern flank of the Bolkar mountain range and coincides with a distinct break in slope (Fig. 4a-d). The main contact is associated with a several hundred-meter-thick fault zone made up of ductile and brittle fault rocks, hereafter referred to as the Ivriz shear zone. Early to middle Eocene sediments unconformably cover the shear zone (Figs. 3, 4d).

At eight localities (Ivriz, Dedeler, Yellice, Kayasaray, Karagöl, Maden, Horoz, and Berendi; Fig. 3, 4a), we systematically analyzed mesoscopic deformation structures and collected oriented samples across the shear zone from structurally lower to higher levels. Foliation and lineation measurements are illustrated in stereoplots in Fig. 3. Microstructural analyses were performed on calcschists, impure marbles and metapelites in standard thin-sections $(\sim 25 \mu \mathrm{m})$ and on calc-mylonites in ultrathin-sections $(<5 \mu \mathrm{m})$. Kinematic indicators such as $c^{\prime}$-type shear bands, asymmetric or rotated porphyroclasts, and grain shape preferred orientations (GSPO) were used to determine the sense of shear (Simpson and Schmid, 1983). Qualitative estimates of metamorphic conditions during deformation are based on ductile and brittle deformation mechanisms of minerals, mechanisms of dynamic recrystallization and the stability of characteristic minerals.

At our type-locality, close to the archaeological site of the Ivriz rock relief, the shear zone dips in NNW-NNE direction with average values of $40^{\circ}$ and is well-exposed along the slope of the range (Fig. 4b). Striations plunge with $\sim 56^{\circ}$ to the north. In the lower parts of the shear zone, originally coarse-grained marbles of the Afyon Zone progressively turn into a several hundred-meterthick zone made of fine-grained calc-mylonites (Fig. 5a-5). Towards structurally higher levels, these are in turn locally transformed into cataclasites along brittle fault zones (Fig. 5a-1). Calc-mylonites usually give a top-NE sense of shear in thin-section as suggested by GSPO, offsets in mineral grains, and deformed porphyroclasts. Sample 15.78 shows layers with slightly different microstructural features (Fig. 6a) and displays two generations of calcite twins, higher-temperature broad ones and lower-temperature thin ones (Ferrill et al., 2004). Dynamic recrystallization occurred by a combination of grain boundary migration (GBM) typical for higher temperatures and subgrain rotation (SGR) typical for lower temperatures (Schmid et al., 1987; Stipp et al., 2002; Fig. 6a). Brittle deformation of quartz in a bookshelf manner in sample $15.83 \mathrm{~B}$ (Fig. 6b) indicates temperature conditions $<280^{\circ} \mathrm{C}$ (Stipp et al.,
2002) during top-NE shearing. Upward, the calc-mylonites develop into a $100 \mathrm{~m}$ thick semi-brittle shear zone comprising low-grade deformed calcschists and marls. Along the boundary between the two zones, a siliciclastic schist (sample 15.84) yielded a ductile top-SW sense of shear based on $\sigma$-clasts in thin-section (Fig. 6c). Semi-brittlely deformed rocks display mesoscopic S-C fabrics with small offsets along shear planes. These indicate overall top-NE and subordinate conjugate top-SW movement (Fig. 5a-1, 2). The semibrittle fault zone is overlain by a discontinuous, up to $80 \mathrm{~m}$-thick sedimentary breccia composed of green, chert-rich rocks, volcaniclastic rocks, and carbonates of the ophiolitic mélange (Fig. 5a-3). It is unconformably overlain by a thick sequence of clast-supported conglomerates reworking marbles and grades upward into Lutetian shallow-marine deposits (Fig. 5a).

Roughly $4 \mathrm{~km}$ west of Ivriz, at the western entrance to Dedeler, foliated gray marbles alternate with calcschists and light green schists. Stretching lineations plunge with $\sim 45^{\circ}$ to the NE. At a high structural level in the foot wall of the contact, meso-scale shear bands in schists suggest a top-NE sense of shear (Fig. 5a-2). The ultrathin-section of a calc-mylonite (sample 15.70) shows foliationparallel domains of largely to completely recrystallized grains as well as domains of highly flattened old grains showing incipient subgrain formation (Fig. 6d). A GSPO of subgrains and recrystallized grains suggests top-NE shearing. The dominant recrystallization process is SGR, where syn-deformational temperatures reached up to $\sim 350^{\circ} \mathrm{C}$ (Ebert et al., 2007). Sample 15.73UT is a marble containing white mica-rich domains and showing an $\mathrm{S}-\mathrm{C}$ fabric in ultra-thin section (Fig. 6e). Deformed white mica between c-type shear bands, as well as mica fish indicate top-NE shearing. Large calcite grains show broad, higher-temperature twins overprinted by dynamic recrystallization, typical for temperatures exceeding $250^{\circ} \mathrm{C}$ (Burkhard, 1993; type 4 twins).

About $7 \mathrm{~km}$ west of Ivriz, along a gully south of Yellice (Fig. 3, Fig. 5b), the shear zone in the foot wall of the contact consists of foliated calcschists, impure marbles, calc-mylonites and green metaphyllites. Foliation dips with $\sim 40^{\circ}$ to the north. Mylonitic marbles and breccias occur at higher structural levels (Fig. 5b-6), whereas calcschists with semi-brittle faults (Fig. 5b-7) and tight folds are found at lower levels. Folds occasionally show an asymmetry (Fig. 5b-8) compatible with a top-N-NE sense of shear. Fold axes roughly trend ENE-WSW. Impure marble sample 15.110 consists of calcite, quartz, white mica, and chlorite. Chlorite mostly grew along the margins of foliation-parallel, calcite-rich domains and adjacent to microcracks. Shear bands indicate top-NE shearing (Fig. 6f). In calc-mylonite sample 15.117UT calcite grain sizes vary considerably (Fig. 6g); domains with smaller grain sizes are most likely the result of low temperature bulging recrystallization (BLG), while larger recrystallized grains exhibit higher temperature GBM recrystallization. In some domains, a GSPO indicates top-NE movement. There, calcite dominantly recrystallized by SGR. Calcschist sample 15.111 shows shear bands supporting overall top-NE transport (Fig. 6h). Northwest of Yellice, the fault zone becomes shallowly dipping, where Pliocene and younger deposits unconformably cover it with only isolated patches of metamorphic rocks cropping out (Fig. 3).

East of Ivriz at the localities Kayasaray, Karagöl, Maden, and Horoz, calc-mylonites of the Afyon Zone are overprinted by cataclastic deformation towards the contact with the ophiolite or ophiolitic mélange. From west to east, the shear zone becomes progressively more steeply inclined into a subvertical orientation (Fig. 3, stereoplot of foliations). Latest Cretaceous to Oligocene sediments in the hanging wall of the contact also reach near-vertical dips and finally become overturned. The steepening trend of units along the Ivriz contact from west to east has been explained by the Eo-Oligocene formation of the eastward intensifying Bolkar Fold (Figs. 3, 4; Clark and Robertson, 2002; Gürer et al., 2016). 

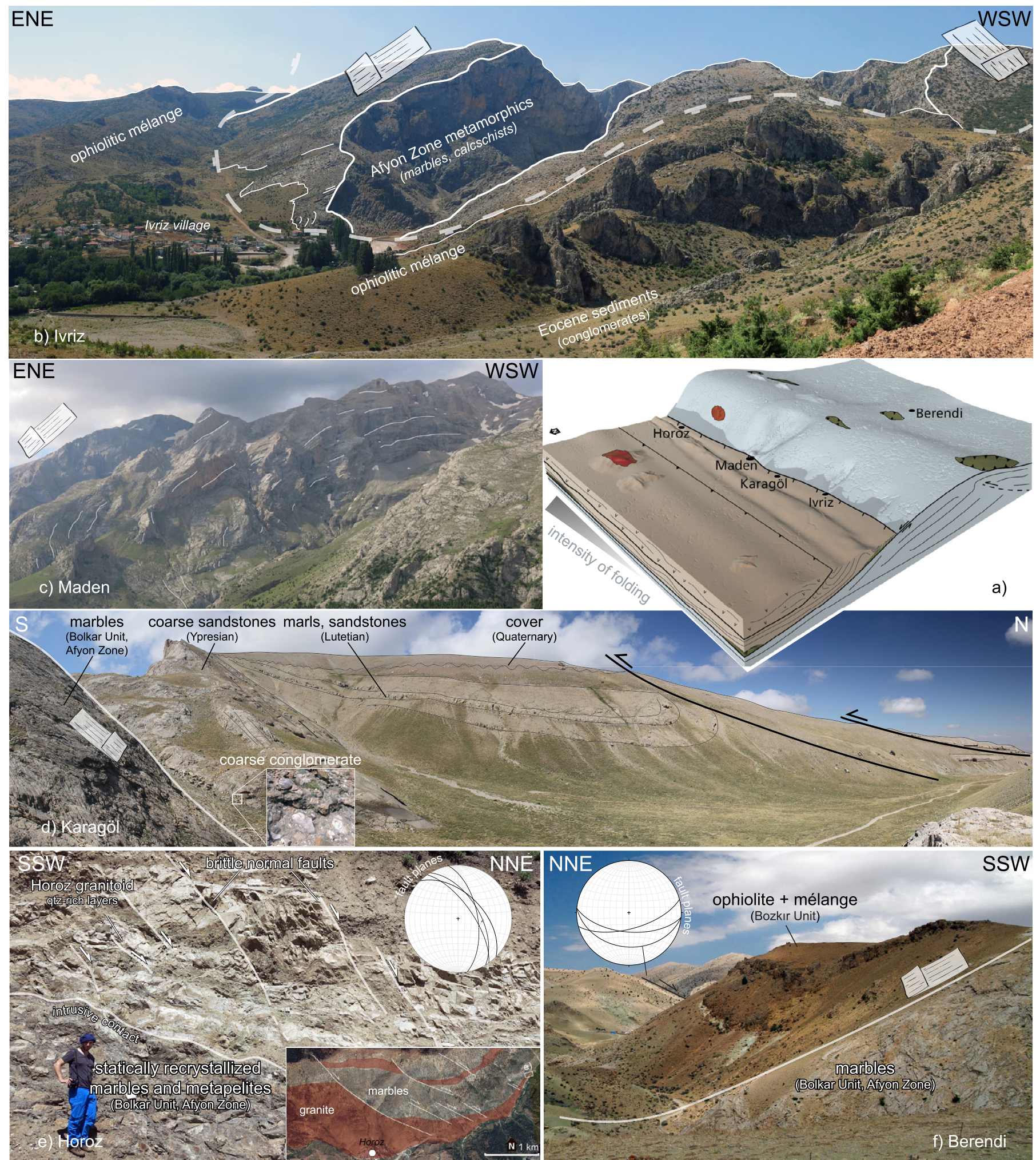

Fig. 4. Field views of the Ivriz shear zone at several localities and associated field relations (b-f). Synthesis block diagram showing the field and age relations along the southern margin of the Ulukışla Basin, where the front of the Bolkar Mountains is incorporated into the Bolkar Fold (a). This results in the eastward steepening of the Ivriz shear zone. Associated outcrop scale field views of the Ivriz shear zone between the Afyon Zone metamorphic rocks in the foot wall and the non-metamorphic hanging wall at several localites: b) Ivriz type locality: HP-metamorphic foot wall rocks are juxtaposed against a metamorphic mélange the hanging wall, which is unconformably overlain by a coarse conglomerate and Eocene sediments. Shear zone plane is marked by arrows. c) Maden: view of the subvertical to overturned limb of the Bolkar Fold, note that image has been reflected to match the orientation of the block diagram. d) Karagöl: HP-metamorphics are unconformably overlain by Eocene sediments. Note that there is an angular unconformity between the basal conglomerates and coarse sandstones (Ypresian; early Eocene) with the overlying marls and sandstones (Lutetian; middle Eocene). The latter record syn-kinematic top-S thrusting related to Bolkar folding. e) Horoz: HP-calschists and marbles are intruded by a granitoid, which itself is dissected by top-NE brittle normal faults on the outcrop and several km-scale (inset satellite imagery (copyright DigitalGlobe, Inc.)). f) Berendi: the contact between the Bozkır Unit and the coarse crystalline HP marbles is marked by a several meter thick cataclastic fault zone in the lowermost part of the mélange. Several brittle top-S high-angle normal faults dissect the marbles and root into the fault zone. 

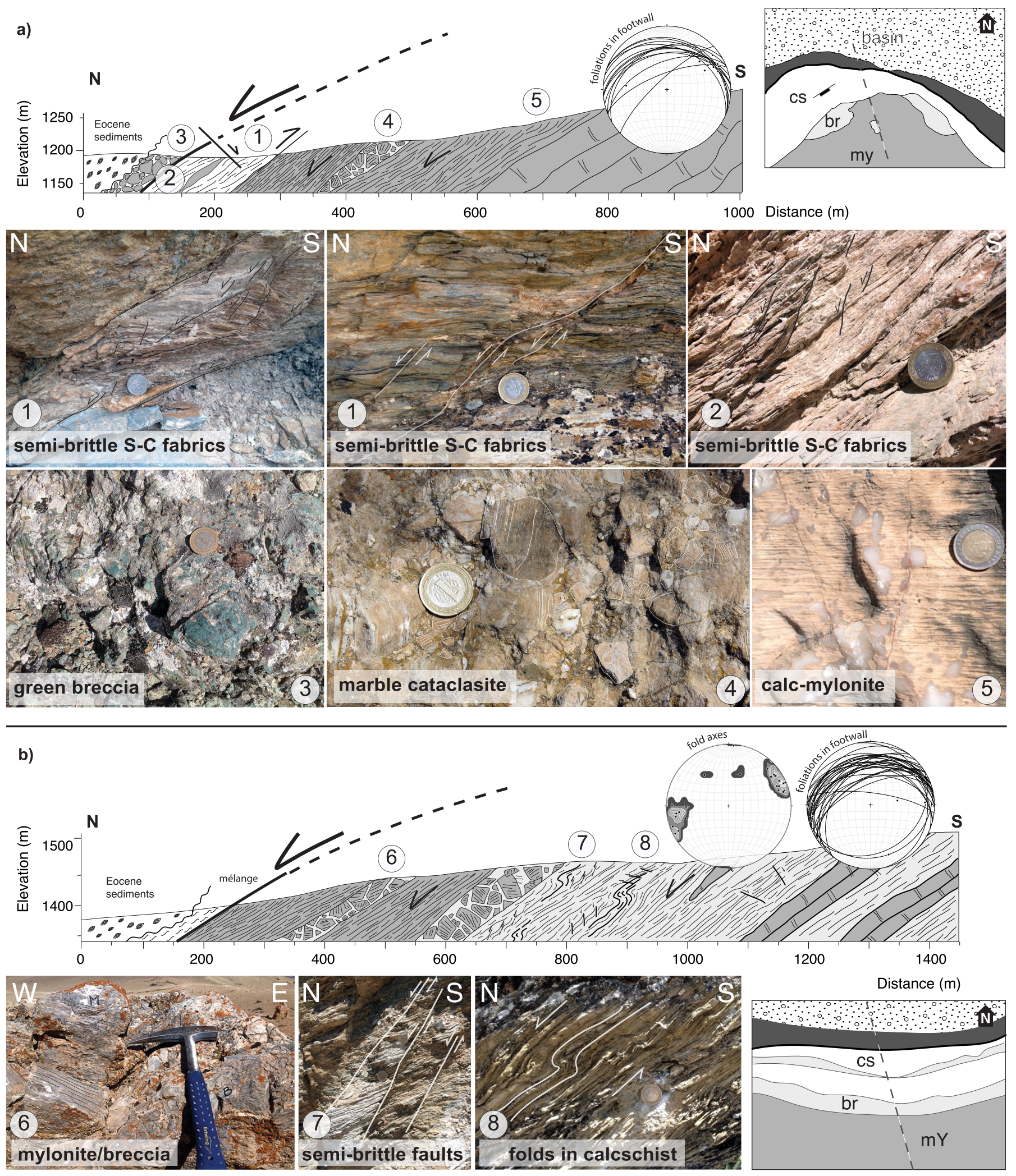

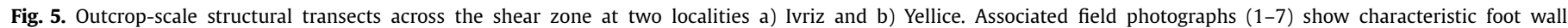

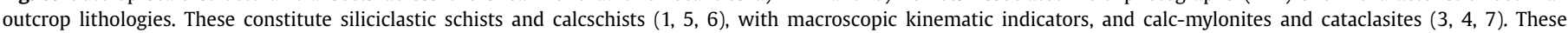

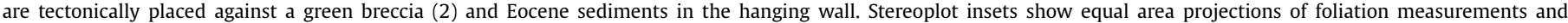
NE-SW trending fold axes $(n=24)$ with $1 \%$ area contour, contour interval $2 \%$.

In calc-mylonite sample 15.164UT (Kayasaray) a GSPO of subgrains indicates top-NE shearing (Fig. 6i). The dominant recrystallization process was SGR with subordinate GBM. Thin, lower- temperature twins can be observed in less recrystallized grains. Sample 15.165 also shows a GSPO indicating top-NE shearing (Fig. 6j). 

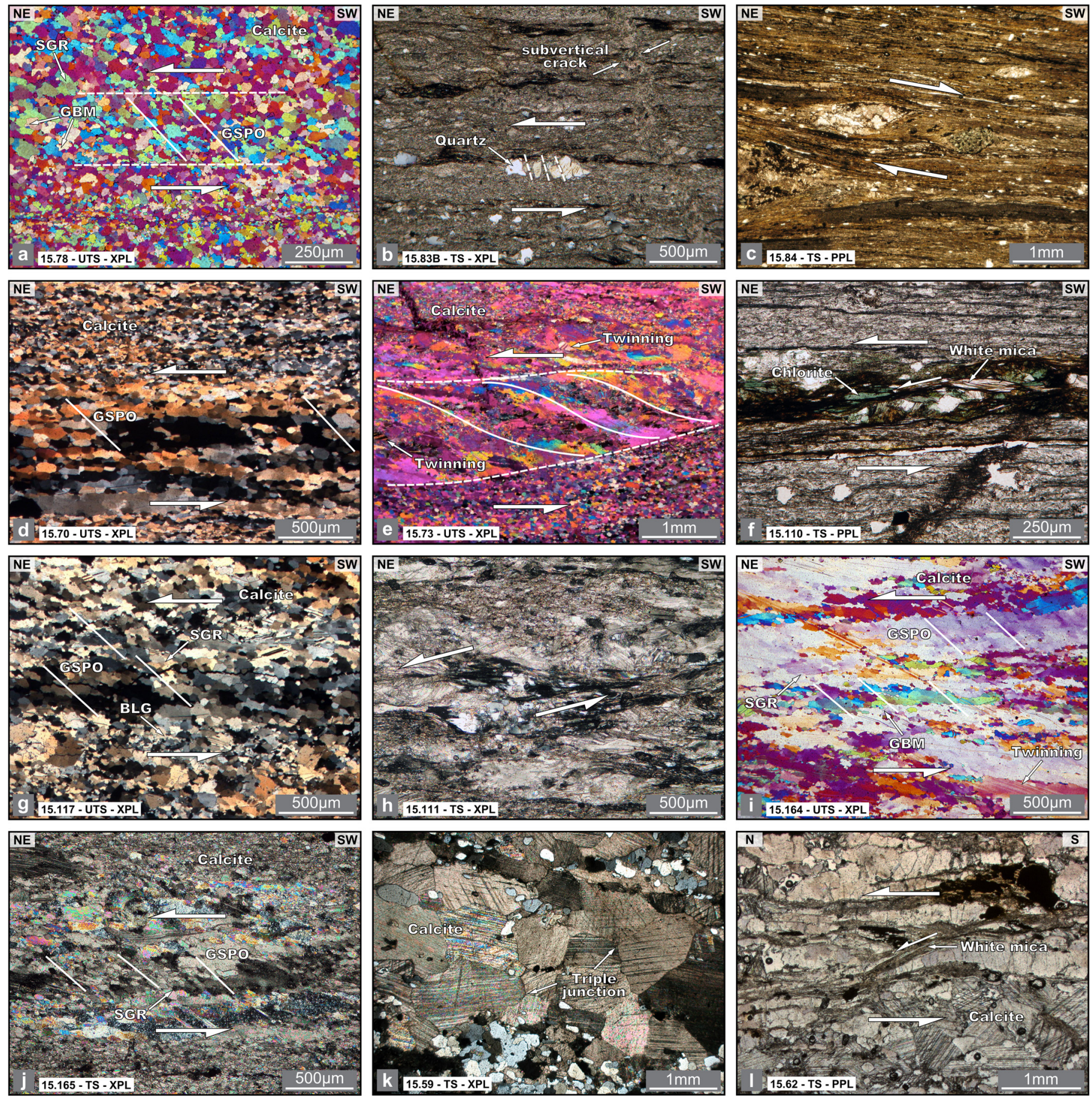

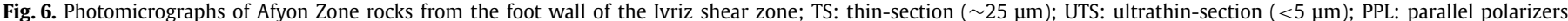

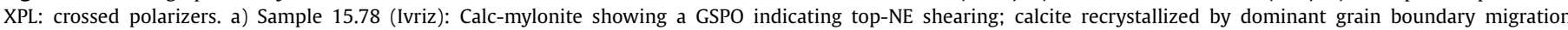

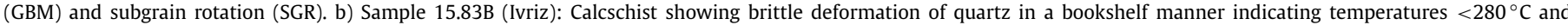

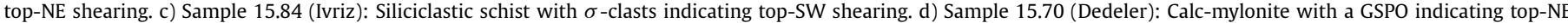

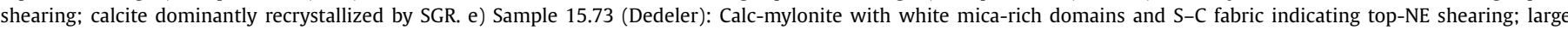

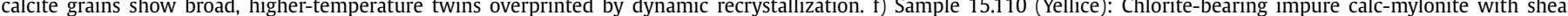

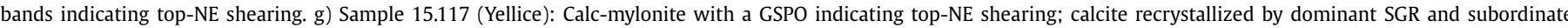

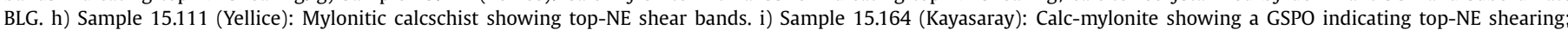

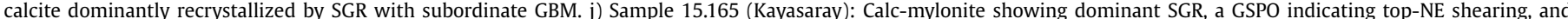

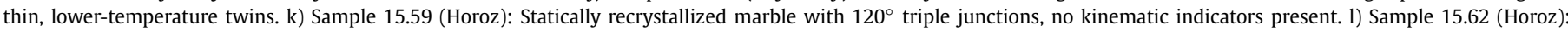
Impure marble with shear band indicating top-N shearing.

Near Horoz (Figs. 3, 4a, e), calc-mylonites are intruded by the Horoz granite and become increasingly overprinted by static recrystallization in the contact aureole towards the intrusion (Fig. 6k). Large calcite grains are equigranular, mostly polygonal in shape, and contain some undulose extinction and twinning in random orientation. The granite itself does not show any signs of ductile deformation. The contact with the overlying mélange is a brittle fault parallel to the main Ivriz tectonic contact and also the Horoz granite itself is dissected by numerous brittle top-NE normal faults on outcrop to several km-scale (Fig. 4e). Mylonites not 
overprinted by static recrystallization and away from the intrusion display kinematic indicators suggesting top-down motions with a top-N sense of shear (Fig. 6l; stereoplot in Fig. 3).

The contact between the ophiolitic mélange in the hanging wall and the Afyon Zone in the foot wall is also exposed near Berendi, $\sim 25 \mathrm{~km}$ to the south of Ivriz (N37.28 ${ }^{\circ}, \mathrm{E} 34.03^{\circ}$, Figs. 3, 4f). There, the contact is marked by a several meter thick cataclastic fault zone in the lowermost part of the mélange. Conclusive kinematic indicators are lacking, as the shear zone is marked by serpentinite with no coherent fabric. Brittle normal faults that root in the main fault zone dissect the hanging wall mélange. Offset along these faults gives a top-N sense of shear. No mylonitic fabrics are found in the coarse crystalline foot wall marbles.

\section{2. $\mathrm{U} / \mathrm{Pb}$ geochronology}

Age constraints were obtained by $\mathrm{U} / \mathrm{Pb}$ isotope dilution thermal ionization mass spectrometry on zircon and baddeleyite $\left(\mathrm{ZrO}_{2}\right)$ grains. Details on laboratory treatment, age calculation, sample characteristics and sample coordinates can be found in the Supplementary Information. Uncertainties in the isotope ratios and the ages are given and plotted at $2 \sigma$ (Fig. 7). Sample locations are shown on the geological map in Fig. 3.

The Horoz granite (Fig. 4e) intruded the Ivriz shear zone after the ductile stage of deformation, but prior to the end of brittle faulting, thus providing a minimum age for the final activity of the structure. Sample HO16 was collected in the upper part of the Afyon foot wall, where the intrusion is found within statically recrystallized marbles of the Afyon Zone and is dissected by numerous brittle normal faults. The analyses of four single zircon grains (Fig. 7; Appendix Table 2) plot in a group near the Concordia curve. Three overlapping analyses from single grains yielded an average ${ }^{206} \mathrm{~Pb} /{ }^{238} \mathrm{U}$ age of $50.27 \pm 0.22 \mathrm{Ma}$. The fourth analysis of a single grain yields a slightly younger age, presumably reflecting some degree of younger $\mathrm{Pb}$ loss, as suggested by the significantly younger analysis of a fraction of four grains plotting at $\sim 36.4 \mathrm{Ma}$.

The Elmalı intrusion crops out in the center of the Ulukışla volcanic center, roughly $10 \mathrm{~km}$ north of the Horoz intrusion (Fig. 3). Two syenite samples (UK25 and EL13) from the center and edge of the Elmalı intrusion were dated to test whether this intrusion may be the same as the Horoz granite and may serve as a displacement marker. Four analyses of zircon fractions from sample UK25 show some scatter which points to the presence of older inherited components. The two youngest overlapping analyses yield an average ${ }^{206} \mathrm{~Pb} /{ }^{238} \mathrm{U}$ age of $56.18 \pm 0.09$ Ma. Sample EL13 contains both zircon and baddeleyite which show some scatter but give mostly overlapping ${ }^{206} \mathrm{~Pb} /{ }^{238} \mathrm{U}$ ages averaging $56.13 \pm 0.17 \mathrm{Ma}$. The discordance with higher ${ }^{207} \mathrm{~Pb} /{ }^{235} \mathrm{U}$ ages of baddeleyite is not uncommon and has variously been attributed to excess ${ }^{231} \mathrm{~Pa}$ (e.g., Amelin and Zaitsev, 2002). The ages obtained from both samples from the intrusion are the same within error.

\subsection{Synthesis and structural interpretations}

A ductile shear zone mainly comprising calc-mylonites occurs in the foot wall of the main tectonic contact between Afyon Zone rocks and the ophiolite and ophiolitic mélange. Kinematic indicators within these mylonites almost exclusively give a top-NE sense of shear (stereoplot in Figs. 3,6). Thin-section analyses showed that ductile deformation led to dynamic recrystallization of originally coarse-grained marbles, whereby calcite was plastically deformed over a range of temperatures, generally lower than peak (blueschist-facies) metamorphic temperatures and subsequently overprinted by cataclastic deformation in uppermost parts of the fault zone associated with the Ivriz shear zone. The dominant recrystallization process is SGR, with subordinate GBM and BLG. Duc-

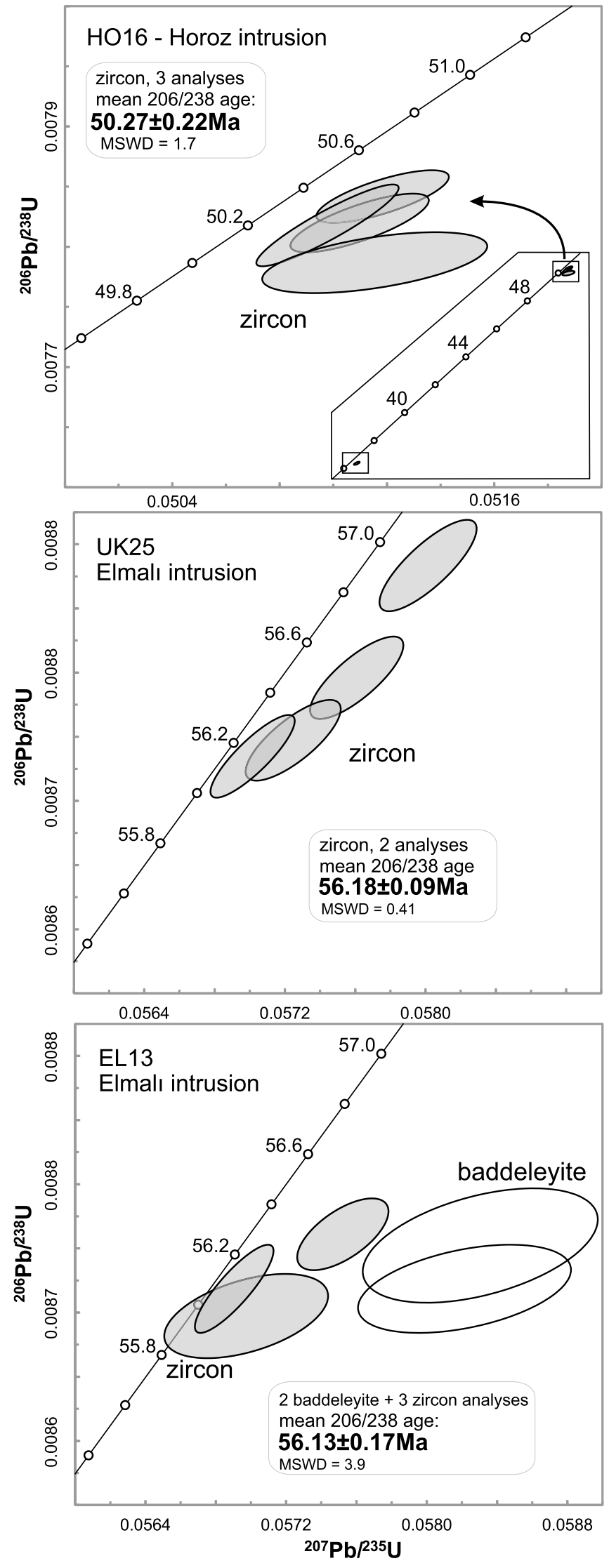

Fig. 7. Concordia diagrams displaying $\mathrm{U} / \mathrm{Pb}$ data for zircon and baddeleyite fractions obtained from the Horoz and Elmalı intrusions. The inset Concordia diagram shows the plots of both measurements, 50.27 Ma and 36.4 Ma, respectively. Sample locations are marked on the geological map; Fig. 3, coordinates are given in Table 2 in the supplementary materials. Ellipses indicate $2 \sigma$-uncertainty. 


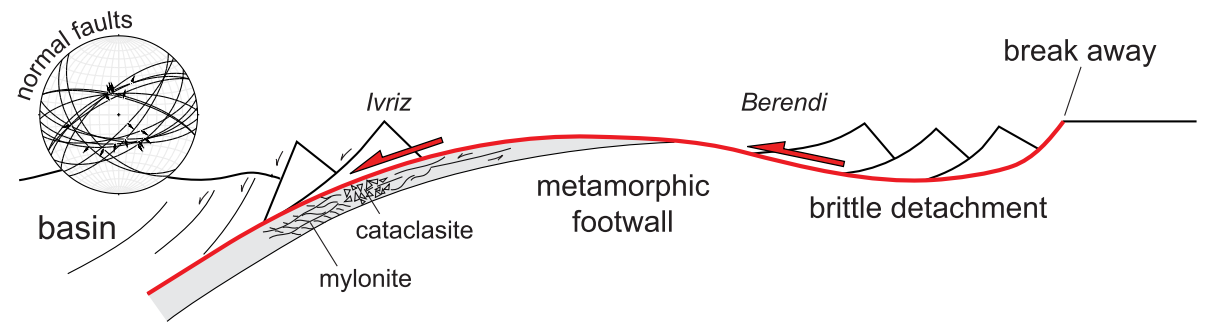

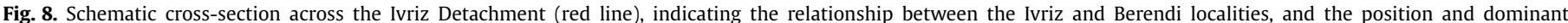

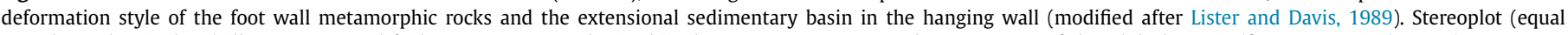
area, lower hemisphere) illustrates normal fault measurements obtained in the Late Cretaceous to Paleocene strata of the Ulukışla Basin (from Gürer et al., 2016).

tile deformation started under lower greenschist-facies metamorphic conditions and temperatures of $\sim 350{ }^{\circ} \mathrm{C}$ (Ebert et al., 2007) and progressively decreased until the cessation of crystal plasticity below $\sim 200^{\circ} \mathrm{C}$ in calcite (Ebert et al., 2007 and references therein) during the latest stages of deformation along the top of the Ivriz shear zone. Often observed incomplete recrystallization of large calcite grains suggests that strain was variably distributed within the shear zone throughout its deformation history. Towards the contact, calcschists and siliciclastic schists become dominant over calc-mylonites. These are characterized by semi-brittle deformation and also show dominant top-NE kinematic indicators. Also observed top-SW shear criteria may be related to deformation during underthrusting of these units and may have formed during retrograde thrusting within an extrusion wedge. Alternatively, they may represent conjugate structures during tectonic thinning of the shear zone. Brittle deformation following ductile and semibrittle deformation was localized along the upper interface with the hanging wall contact, as is typical for normal faults. However, cataclastic horizons within calc-mylonites are also occasionally observed at lower structural levels.

Our observations show that over a $\sim 120 \mathrm{~km}$ distance, the Afyon Zone is bounded at the top by a ductile to brittle shear zone that juxtaposes HP-metamorphic rocks in the foot wall against ophiolitic mélange or ophiolite in the hanging wall. Both are unconformably covered by Eocene non-metamorphic sediments of the Ulukışla Basin. Kinematic field observations and thin section analyses consistently indicate a top-NE normal fault motion (Figs. 3-6), compatible with syn-sedimentary extension recorded by the basal basin stratigraphy (Gürer et al., 2016; stereoplot in Fig. 8). These relations show that the Ivriz shear zone omitted a large part of the crust defining it as an extensional structure, hereafter named Ivriz Detachment. We interpret the exclusively brittle contact at Berendi as the southern continuation of the detachment (Fig. 8). It may represent an older, now flat-lying portion of the detachment that became inactive when the main fault moved step-wise upwards towards higher structural levels (e.g., Lister and Davis, 1989). Exhumation was therefore modest along this particular segment of the detachment. This geometry requires that the Ivriz Detachment was folded, perhaps as the western, weakly deformed part of the Bolkar Fold, or as a result of back-tilting during detachment faulting, or both. Retro-deformation of the Bolkar Fold brings the detachment into an originally low-angle, north-dipping orientation along the entire length of the northern margin of the Tauride mountain range. Unconformable sedimentary cover rocks of Eocene (Ypresian-Lutetian) age deposited during shortening at Karagöl (Fig. 4d) demonstrate that the activity of the Ivriz Detachment must have ended prior to the end of the early Eocene ( $\sim 48 \mathrm{Ma}$ ), by which time the Bolkar Fold (Jaffey and Robertson, 2001) started forming (Gürer et al., 2016). Extension must have continued until after $\sim 50 \mathrm{Ma}$, as constrained by the syn-kinematic Horoz granite (Fig. 4e).

\section{Discussion}

\subsection{Extensional exhumation history of the Afyon Zone}

Field and thin-section observations show that the Afyon Zone was exhumed along the top-NE Ivriz Detachment. Its temporal and spatial evolution is illustrated in Fig. 9. We constrain the timing of activity of this major structure based on the following data: (1) The Afyon Zone contains a stratigraphical column that reaches the Maastrichtian (Göncüoglu et al., 1992) and metamorphism must therefore be younger than $\sim 70 \mathrm{Ma}$. (2) Radiometric ${ }^{40} \mathrm{Ar} /{ }^{39} \mathrm{Ar}$ ages of $\sim 67-62$ Ma for the Afyon Zone are interpreted as retrograde mineral growth ages after peak blueschist metamorphism (Özdamar et al., 2013; Pourteau et al., 2013). Since the Afyon Zone was at $\mathrm{P}-\mathrm{T}$ conditions equivalent to those of blueschist facies $\left(10 \mathrm{kbar} / 375^{\circ} \mathrm{C}\right)$ before exhumation, we consider this ${ }^{40} \mathrm{Ar} /{ }^{39} \mathrm{Ar}$ range of ages to indicate the maximum ages for the onset of exhumation along the Ivriz Detachment. (3) The $50.27 \pm 0.22 \mathrm{Ma}$ age of the Horoz intrusion, which intruded when the Afyon Zone was already exhumed to brittle, upper crustal conditions, indicates that activity of the detachment continued after $\sim 50 \mathrm{Ma}$. (4) synkinematic early to middle Eocene sediments unconformably cover the detachment and record $\mathrm{N}-\mathrm{S}$ shortening, demonstrating the arrest of the detachment prior to $\sim 49$ Ma (Ypresian-Lutetian boundary). Therefore, the Ivriz Detachment was active sometime after $\sim 65 \mathrm{Ma}$ and until shortly after $\sim 50 \mathrm{Ma}$. In western Anatolia, late Paleocene sediments unconformably cover the Afyon Zone metamorphic rocks (Candan et al., 2005), suggesting that there the exhumation started slightly earlier than in Central Anatolia.

Our field and thin-section observations show that ductile deformation related to the detachment largely occurred under lower blueschist to sub-greenschist facies conditions. The presence of glaucophane-epidote bearing rocks within the Afyon Zone (Blumenthal, 1956) and the estimated P-T conditions of the carpholite-chloritoid bearing rocks of the rest of Afyon Zone (10 kbar $/ 375^{\circ} \mathrm{C}$; Pourteau et al., 2014) suggest that not all exhumation of the Afyon Zone can be ascribed to the activity of the Ivriz Detachment. The first phase of exhumation brought these rocks from blueschist to lower blueschist-facies conditions, perhaps as a result of channelized exhumation along the subduction zone (e.g., Agard et al., 2010; Jolivet et al., 2003). The few top-SSW shear indicators that we obtained from the foot wall formed at temperatures indicative of greenschist or lower blueschist-facies conditions. This may reflect the thrust motion during subduction, before peak metamorphism, or thrusting at the base of the exhuming subduction channel. The main zone facilitating this return flow during overall top-(N)NE sense of normal motion was located structurally higher (Fig. 9). The amount of exhumation is estimated based on thin-section observations that suggest a temperature drop from $\sim 350^{\circ} \mathrm{C}$ to $<200^{\circ} \mathrm{C}$ during detachment activity. Since the rocks in the foot wall were metamorphosed at some 10-12 kbar (Pourteau et al., 2014), exhumation amounted to some $40 \mathrm{~km}$ between Late Cretaceous and early Eocene time. 


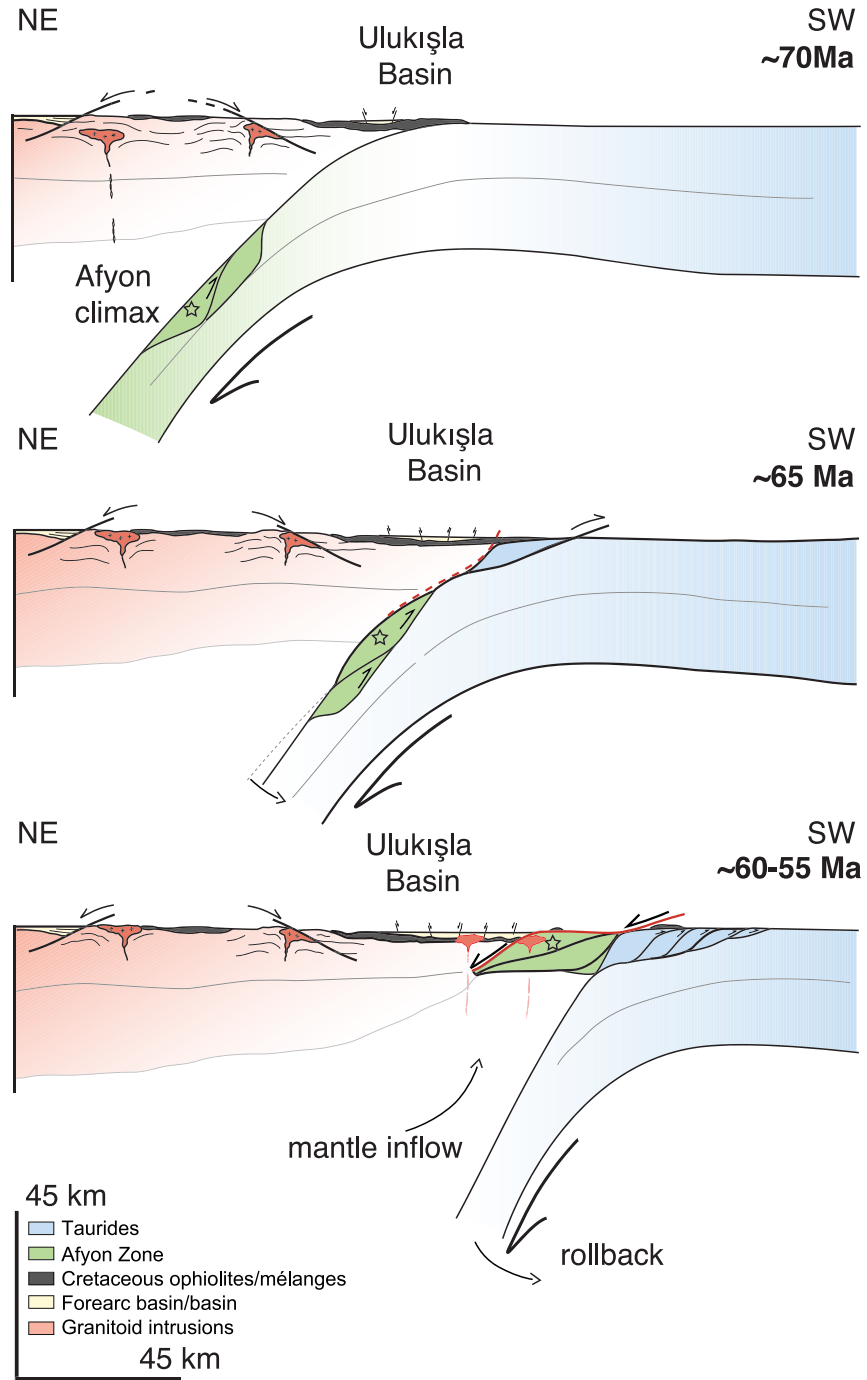

Fig. 9. Conceptual diagram illustrating the evolution of the Ivriz Detachment and its role in the exhumation of the Afyon Zone, and the extent of the Central Anatolian metamorphic domain, including the Kırşehir Block with associated detachments. Abbreviations used for ophiolites and associated mélanges: MS = Mersin $\mathrm{BE}=$ Berendi, $\mathrm{KT}=$ Kizıltepe, $\mathrm{AH}=$ Alihoca. The red line marks the location of the Ivriz Detachment. a) Afyon peak-metamorphic conditions are marked by a star $\left(10 \mathrm{kbar} / 375^{\circ} \mathrm{C}\right)$, and are contemporaneous with onset of extensional forearc basin sedimentation in the Ulukışla Basin. b) Afyon Zone decouples and starts exhuming together with mélange, while extensional forearc basin sedimentation continues. c) Elmalı ( $\sim 56 \mathrm{Ma}$ ) and Horoz granitoid $(\sim 50 \mathrm{Ma})$ intrude into the detachment at upper crustal levels. Abbreviations: $\mathrm{c}=$ crust, $\mathrm{lc}=$ lower crust, $\mathrm{m}=$ mantle, HO $=$ Horoz intrusion, $\mathrm{EL}=$ Elmalı intrusion. Note that this conceptual evolutionary cross-section does not illustrate the relations south of the northern Neotethyan subduction zone below the Pontides, shown in Gürer et al. (2016).

Our new $50.27 \pm 0.22$ Ma crystallization age of the Horoz intrusion is comparable to the $50.6 \pm 2.4$ to $49.1 \pm 1.0$ Ma age (Parlak et al., 2013), but younger than the unpublished age of $56 \mathrm{Ma}$ quoted by Kadioglu and Dilek (2010). The latter compares instead with the ages of $56.18 \pm 0.09 \mathrm{Ma}$ and $56.13 \pm 0.17 \mathrm{Ma}$ obtained for the Elmalı intrusion, suggesting the presence of distinct intrusive phases in the Horoz intrusion, including one that is coeval with the Elmalı intrusion. This may suggest that the two granitoid bodies were originally part of one contiguous granitoid body of which the Elmalı body formed the shallow top and the Horoz body the deeper underpinnings. If this is correct, the granites, which are separated by $\sim 10 \mathrm{~km}$ in a direction parallel to extension accommodated by the detachment, may serve as markers to estimate the displacement along the Ivriz Detachment since $\sim 56$ Ma. Assum- ing an original dip of $30^{\circ}$ for the detachment, displacement would be on the order of $\sim 12 \mathrm{~km}$. This is a minimum displacement estimate, since the area was subsequently shortened by a few $\mathrm{km}$.

\subsection{Relationship between the Ivriz Detachment and the formation of the Ulukışla Basin}

Analysis of the sedimentation and deformation history of the Ulukışla Basin in the hanging wall of the Ivriz Detachment provides further constraints on the age of activity and role of the detachment. We explore how the phases of uplift and subsidence in that basin determined by Gürer et al. (2016) may be reconciled with the underthrusting and exhumation of the major units below the ophiolites that lie at the floor of this basin. The history of subsidence and uplift started with crystallization of the $\sim 92 \mathrm{Ma}$ old ocean floor with a supra-subduction zone signature that likely formed shortly after subduction initiation below the Anadolu Plate (Dilek et al., 1999; Gürer et al., 2016). We interpret the first phase of uplift and erosion of the ophiolites before $\sim 75 \mathrm{Ma}$, as an effect of the underthrusting of the buoyant Kirşehir Block below the ophiolites at $\sim 90-85 \mathrm{Ma}$, resulting in forearc uplift. Subsequently, subsidence of the ophiolites led to deposition of deep-marine Campanian limestones and clastics (Gürer et al., 2016), temporally coinciding with underthrusting of the likely oceanic IntraTauride basin (Fig. 2). Similarly, farther west there is a gap in the subducted record between the subduction/accretion/exhumation of the Tavşanlı Zone ( $95-80 \mathrm{Ma})$ and the subduction of the Afyon Zone at $\sim 70 \mathrm{Ma}$. As the structurally-lower and last-accreting parts of the Tavşanlı Zone are continental in origin (Plunder et al., 2015), subduction of an intervening ocean plate or deep basin must have taken place between the last stages of Tavşanlı Zone subduction and the onset of Afyon Zone subduction. The subduction of an intervening ocean (basin) must have been non-accretionary, either associated with no net accretion or with subduction erosion. Underthrusting of that thinner and less buoyant crust led to relative subsidence in the forearc. Renewed uplift in the Maastrichtian likely reflected the arrival of the Afyon Zone margin of the Tauride platform in the trench. From the sedimentary facies and kinematic analyses, it was inferred that the accommodation space for the Maastrichtian to Paleocene basin fill formed due to the activity of a major north-dipping normal fault along the southern basin margin (Gürer et al., 2016; Fig. 3, stereoplot in Fig. 8), in tandem with E-W extensional normal faults in the north of the basin. We now interpret the major, north-dipping, basin-bounding normal faults to coincide with or root into the Ivriz Detachment and consequently interpret the uppermost Cretaceous-lower Eocene Ulukışla Basin as the supra-detachment associated with the activity of the Ivriz Detachment. The age and direction of extensional deformation inferred from the basal stratigraphy of the southern margin of the Ulukışla Basin ( 65-56 Ma) overlaps and is consistent with the age range inferred for detachment activity. We note that also to the north of the Ulukışla Basin, $\sim \mathrm{E}-\mathrm{W}$ extensional detachments may have been active exhuming the Niğde Massif (e.g., Gautier et al., 2008); Therefore, the basin can be considered to have formed during the activity of both detachment systems. The Ulukışla Basin shows that extension and subsidence in the hanging wall of the Ivriz Detachment occurred at $\sim 65-56 \mathrm{Ma}$, after which the detachment must have remained active until after emplacement of the Horoz intrusion at $\sim 50 \mathrm{Ma}$. This suggests that the extensional unroofing of the Afyon Zone started soon after its accretion to the Anatolian collage. 


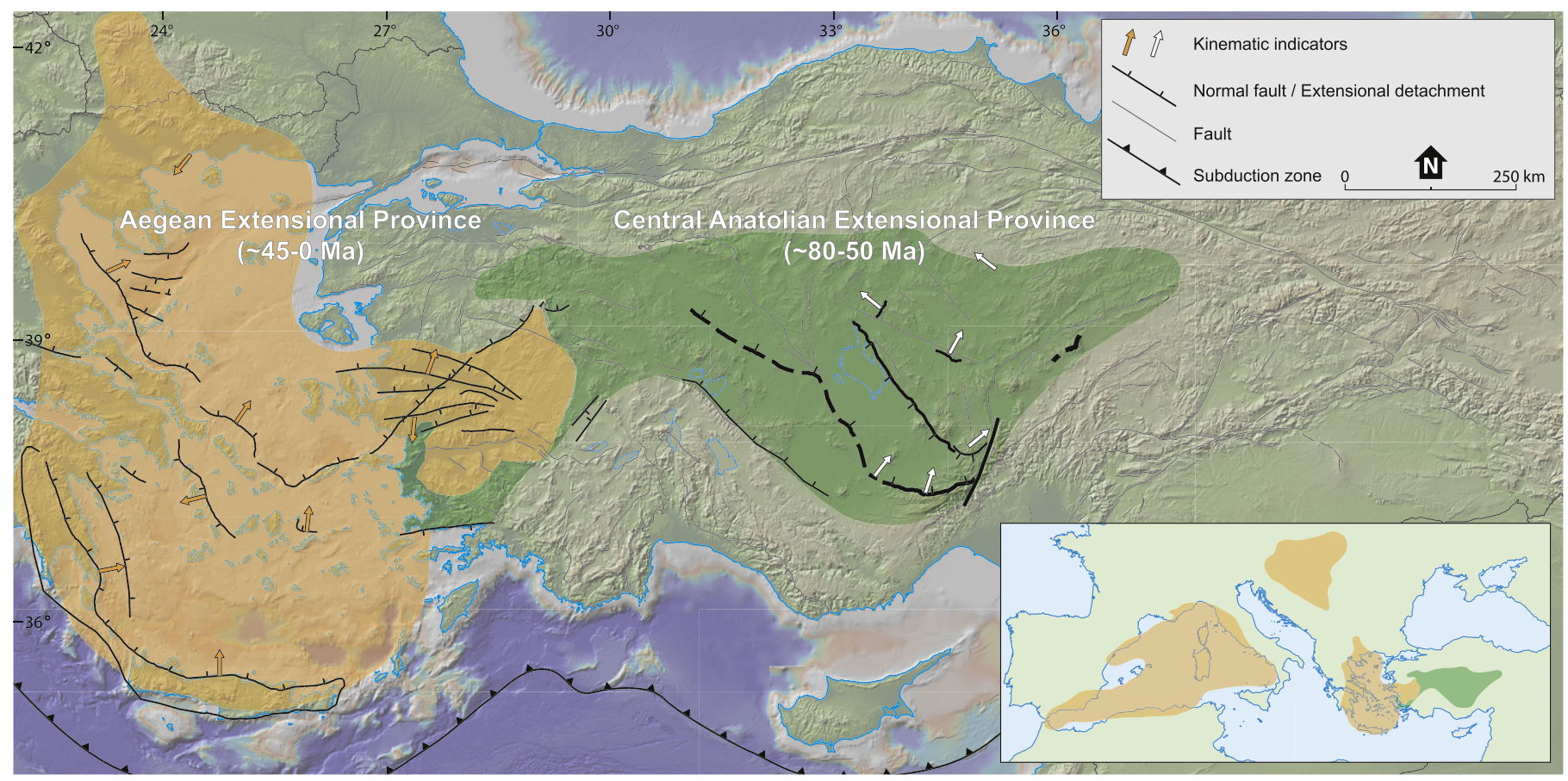

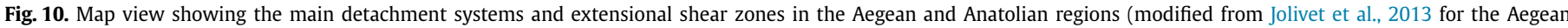

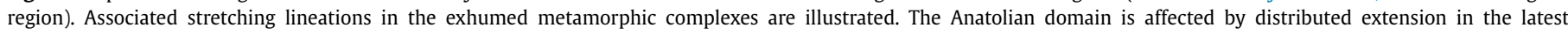

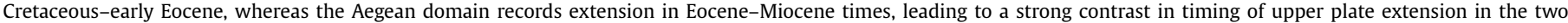
regions. Other major Neogene extensional regions are illustrated in the inset (bottom right).

\subsection{The Late Cretaceous-early Eocene Central Anatolian extensional province}

Our investigations show that the Ivriz Detachment is a regionally important structure that was responsible for extensional exhumation of the Afyon Zone to the surface from 65-50 Ma over an along-strike distance of at least $120 \mathrm{~km}$. To the east, the detachment is cut by the Ecemis fault zone that was active during the late Eocene to Oligocene, synchronous with $\mathrm{N}-\mathrm{S}$ shortening in the Ulukışla Basin (Gürer et al., 2016). Given the abrupt crosscutting of the Ivriz Detachment by the Ecemiş fault zone, we expect that the detachment system formerly continued to the east of this fault where exhumed Afyon Zone rocks are exposed for at least another $40 \mathrm{~km}$ along the SW margin of the Sivas Basin (MTA, 2002). To the northwest of our study area, the Afyon Zone is exposed in isolated hills overlain by klippen of ophiolite and ophiolitic mélange within the Konya plain with relationships similar to those at the Ivriz Detachment. The exact role of extension in the unroofing of the Afyon Zone outside our study area and possible variations in extension directions and timing, require further study. However, based on the presently available evidence we suggest that much of the Afyon Zone was extensionally exhumed.

In the case of the Kırşehir Block E-W-directed extensional unroofing was previously documented to have occurred after at least $\sim 75 \mathrm{Ma}$ and before the Lutetian (Gautier et al., 2002; Lefebvre et al., 2011). Combined with our new data, (which unlike the Kırşehir Block have not yet been corrected for post-early Eocene vertical axis rotations, Gürer et al., 2017), this suggests that Central Anatolia was the locus of a major, Late Cretaceous-Paleocene extensional province (Fig. 10) whereby exhumation of units previously underthrusted below oceanic lithosphere occurred in an overriding plate position above an active subduction zone. Similar to the Aegean region, southward and westward younging accretion was followed by southward and westward younging exhumation (e.g., Menant et al., 2016 and references therein), which may be well envisioned by the 'caterpillar walk' exhumation style illustrated by Tirel et al. (2013).
The metamorphic rocks of Central Anatolia cover an area similar in size to the Aegean metamorphic province (Fig. 10), whereby the Afyon Zone may be equivalent to the HP-LT metamorphic belt of Crete and the Peloponnese, and the Kırşehir Block may be equivalent to the Cyclades.

\subsection{Implications for Eastern Mediterranean rollback evolution}

The Aegean and Central Anatolian extensional provinces have similar dimensions (Fig. 10), but the latter is considerably older. Aegean extension started in middle Eocene time ( 45 Ma; e.g., Brun and Sokoutis, 2010; and references therein) after cessation of the Central Anatolian extensional on the Ivriz and Kırşehir detachments. This age contrast of Aegean and Central Anatolian extension may have important implications for the geometry and dynamics of the down-going African Plate lithosphere in the eastern Mediterranean. In an overall convergent setting, major overriding plate extension requires divergence between the trench and the overriding plate, typically interpreted as the consequence of slab rollback (e.g., Royden, 1993), although similar extension may arise from absolute overriding plate motion away from a mantle-stationary trench (Gürer et al., 2016). The different ages of overriding plate extension in the Aegean and Central Anatolian systems may thus suggest that the African slab underlying the Anatolian segment was able to move relative to the slab underlying the Aegean system during extension in both segments.

Seismic tomographic images of the modern Eastern Mediterranean upper mantle show that the African slab consists of at least three upper mantle slab segments separated by slab edges and windows: the Aegean, the Antalya, and the Cyprus slabs (Biryol et al., 2011; van Hinsbergen et al., 2010). It has been suggested that the eastern Aegean slab edge must have formed at least by middle Miocene time (Jolivet et al., 2013; van Hinsbergen et al., 2010). Additionally, it was suggested that the disconnection between the Antalya and Cyprus slabs must have existed since at least late Miocene time (Schildgen et al., 2012). At this stage, it 
remains uncertain whether the latest Cretaceous-Paleocene segmentation, which we deduce from the age difference between the Central Anatolian and Aegean extensional provinces, was accommodated along a similar sharp disconnection. If there was such a sharp disconnection, one would expect a narrow fault zone as surface expression of a STEP fault, which currently is not obvious from the known geology. Alternatively, the latest Cretaceous to early Eocene roll-back of the Central Anatolian segment may have been the result of eastward increasing roll-back of the trench through a gradual clockwise rotation of the eastern part of the slab. In this case, the slab may have remained contiguous with the amount of extension gradually decreasing from central to western Anatolia. Since $65 \mathrm{Ma}$, up to $900 \mathrm{~km}$ of Africa-Europe convergence has occurred (e.g., van Hinsbergen et al., 2010) and the lithosphere that subducted in the Paleocene now likely resides in the lower mantle. Any tomographic evidence for early slab segmentation is therefore best assessed from the lower mantle structure. In addition, Neogene and Quaternary magmatism in eastern Greece and western Turkey has been geochemically interpreted to relate to the presence of a slab edge below the region (e.g., Klaver et al., 2016). Similar studies on the pre-Neogene magmatic record in this region may further indicate whether pre-Neogene slab edges existed.

\section{Conclusions}

Up to now, the process of exhumation of the $\sim 800 \mathrm{~km}$ long HP/LT Afyon Zone metamorphic belt was poorly understood. Here we document for the first time a regionally important structure, the Ivriz Detachment, juxtaposing the Afyon Zone against nonmetamorphic rocks. It can be traced for $>120 \mathrm{~km}$ along the northern margin of the Bolkar mountain range. The contact is a ductileto-brittle fault zone characterized by a strong tectonic excision as indicated by the contrasting metamorphic grades of foot wall and hanging wall units. We suggest that this structure played a key role in the exhumation of the Afyon Zone metamorphic rocks from greenschist-facies conditions by normal-sense structural attenuation of the overriding plate.

The timing of activity of the Ivriz Detachment is bracketed between the $\sim 67-62 \mathrm{Ma}{ }^{40} \mathrm{Ar} /{ }^{39} \mathrm{Ar}$ retrograde mineral growth ages of the Afyon Zone metamorphic rocks, an unconformable early to middle Eocene sedimentary cover, and the $\sim 50$ Ma syn-tectonic Horoz granite intruding the Afyon Zone when it was at brittle, upper crustal conditions, but prior to the arrest of detachment faulting. Previous kinematic analysis of the Ulukışla Basin in the immediate hanging wall of the detachment has shown that this basin was bounded by a major north-dipping normal fault during latest Cretaceous to Paleocene basin subsidence. Consequently, we interpret the Ulukışla Basin as a supra-detachment basin genetically related to the Ivriz Detachment in the south (perhaps in tandem with extensional detachments to the north of the basin exhuming the Niğde Massif).

Combining our new data with previously documented extensional exhumation of the Kırşehir Block, we suggest that the $\sim 300$ $\times 400 \mathrm{~km}$ region of Central Anatolia presently occupied by metamorphic rocks has been exhumed in a Late Cretaceous to Paleocene $(\mathrm{N}) \mathrm{E}-(\mathrm{S}) \mathrm{W}$ extensional province. This extensional province is similar in size to the Aegean extensional province, but formed prior to the onset of Aegean extension. Since overriding plate extension above a subduction zone requires relative motion between the subducting slab and the overriding plate, the contrast in the ages of the Central Anatolian and Aegean extensional provinces implies that the underlying slabs must have moved relative to each other since the latest Cretaceous.

\section{Acknowledgements}

DG, AP, and DJJvH acknowledge financial support through ERC Starting Grant 306810 (SINK). DJJvH acknowledges funding through NWO Vidi grant 864.11.004. Dirk Simon, Nur Güneli and Nuretdin Kaymakci are thanked for field assistance. DG thanks Gordon Lister for a fruitful discussion about detachments during his visit to Utrecht and John Wakabayashi for discussion regarding the broader temporal tectonic context of this work. Nils Jung, Leonard Bik and Willy Tschudin provided excellent (ultra)-thin sections. Gunborg Bye Fjeld assisted in the Oslo mineral separation laboratory, and Ton Markus (UU Cartography) with illustrations. We thank Laurent Jolivet and two anonymous reviewers for their constructive reviews.

\section{Appendix A. Supplementary material}

Supplementary material related to this article can be found online at https://doi.org/10.1016/j.epsl.2017.10.008.

\section{References}

Agard, P., Searle, M.P., Alsop, G.I., Dubacq, B., 2010. Crustal stacking and expulsion tectonics during continental subduction: P-T deformation constraints from Oman. Tectonics 29. http://dx.doi.org/10.1029/2010TC002669.

Amelin, Y., Zaitsev, A.N., 2002. Precise geochronology of phoscorites and carbonatites: the critical role of U-series disequilibrium in age interpretations. Geochim. Cosmochim. Acta 66, 2399-2419.

Biryol, B.C., Beck, S.L., Zandt, G., Özacar, A.A., 2011. Segmented African lithosphere beneath the Anatolian region inferred from teleseismic P-wave tomography. Geophys. J. Int. 184, 1037-1057. http://dx.doi.org/10.1111/j.1365246X.2010.04910.X.

Blumenthal, M.M., 1956. Yüksek Bolkardağın kuzey kenar bölgelerinin ve batı uzantılarının jeolojisi: (Güney Anadolu Torosları). Maden Tetkik ve Arama Enstitüsü.

Brun, J.-P., Sokoutis, D., 2010. 45 my of Aegean crust and mantle flow driven by trench retreat. Geology 38, 815-818.

Burkhard, M., 1993. Calcite twins, their geometry, appearance and significance as stress-strain markers and indicators of tectonic regime: a review. J. Struct. Geol. 15, 351-368

Candan, O., Cetinkaplan, M., Oberhänsli, R., Rimmelé, G., Akal, C., 2005. Alpine high-P/low-T metamorphism of the Afyon Zone and implications for the metamorphic evolution of Western Anatolia, Turkey. Lithos 84, 102-124. http:// dx.doi.org/10.1016/j.lithos.2005.02.005.

Clark, M., Robertson, A., 2002. The role of the Early Tertiary Ulukisla Basin, southern Turkey, in suturing of the Mesozoic Tethys ocean. J. Geol. Soc. Lond. 159, 673-690. http://dx.doi.org/10.1144/0016-764902-015.

Dilek, Y., Thy, P., Hacker, B., Grundvig, S., 1999. Structure and petrology of Tauride ophiolites and mafic dike intrusions (Turkey): implications for the Neotethyan ocean. Geol. Soc. Am. Bull. 111, 1192-1216. http://dx.doi.org/10.1130/0016-7606 (1999) $111<1192:$ SAPOTO>2.3.CO;2.

Dokuz, A., Aydincakir, E., Kandemir, R., Karsli, O., Siebel, W., Derman, A.S., Turan, M., 2017. Late Jurassic magmatism and stratigraphy in the Eastern Sakarya zone, Turkey: evidence for the slab breakoff of Paleotethyan oceanic lithosphere. J. Geol. 125, 1-31.

Ebert, A., Rieke-Zapp, D., Herwegh, M., Ramseyer, K., Gnos, E., Decrouez, D., 2007. Quantitative analysis of microstructures of coarse-grained marbles: an approach using bireflectance of calcite to visualize the microstructure. Rend. Soc. Geol. Ital. Nuova Ser. 5, 81-82.

Faccenna, C., Becker, T.W., Auer, L., Billi, A., Boschi, L., Brun, J.P., Capitanio, F.A., Funiciello, F., Horvàth, F., Jolivet, L., et al., 2014. Mantle dynamics in the Mediterranean. Rev. Geophys. 52, 283-332.

Ferrill, D.A., Morris, A.P., Evans, M.A., Burkhard, M., Groshong, R.H., Onasch, C.M., 2004. Calcite twin morphology: a low-temperature deformation geothermometer. J. Struct. Geol. 26, 1521-1529.

Gautier, P., Bozkurt, E., Bosse, V., Hallot, E., Dirik, K., 2008. Coeval extensional shearing and lateral underflow during Late Cretaceous core complex development in the Niğde Massif, Central Anatolia, Turkey. Tectonics 27. http://dx.doi.org/10.1029/2006TC002089.

Gautier, P., Bozkurt, E., Hallot, E., Dirik, K., 2002. Dating the exhumation of a metamorphic dome: geological evidence for pre-Eocene unroofing of the Nigde Massif (Central Anatolia, Turkey). Geol. Mag. 139, 559-576. http://dx.doi.org/10.1017/S0016756802006751.

Göncüoglu, M.C., Özcan, A., Turhan, N., Ișık, A., 1992. Stratigraphy of the Kütahya Region. A Geotraverse Across Suture Zone in NW Anatolia. MTA Publ., Ankara, pp. 3-8. 
Gürer, D., Hinsbergen, D.J.J., Matenco, L., Corfu, F., Cascella, A., 2016. Kinematics of a former oceanic plate of the Neotethys revealed by deformation in the Ulukışla basin (Turkey). Tectonics 35, 2385-2416.

Gürer, D., van Hinsbergen, D.J.J., Özkaptan, M., Creton, I., Koymans, M.R., Cascella, A., Langereis, C.G., 2017. Paleomagnetic constraints on Cenozoic verticalaxis rotations in the Central and Eastern Taurides, Turkey. https://doi.org/ 10.5194/se-2017-66.

Isik, V., Lo, C.-H., Göncüoğlu, C., Demirel, S., 2008. ${ }^{39} \mathrm{Ar} /{ }^{40} \mathrm{Ar}$ ages from the Yozgat Batholith: preliminary data on the timing of late cretaceous extension in the Central Anatolian Crystalline Complex, Turkey. J. Geol. 116, 510-526. http:// dx.doi.org/10.1086/590922.

Isik, V., Uysal, I.T., Caglayan, A., Seyitoglu, G., 2014. The evolution of intraplate fault systems in central Turkey: structural evidence and $\mathrm{Ar}-\mathrm{Ar}$ and $\mathrm{Rb}-\mathrm{Sr}$ age constraints for the Savcili Fault Zone. Tectonics 33, 1875-1899.

Jaffey, N., Robertson, A.H.F., 2001. New sedimentological and structural data from the Ecemis Fault Zone, southern Turkey: implications for its timing and offset and the Cenozoic tectonic escape of Anatolia. J. Geol. Soc. Lond. 158, 367-378. http://dx.doi.org/10.1144/jgs.158.2.367.

Jolivet, L., Faccenna, C., Goffé, B., Burov, E., Agard, P., 2003. Subduction tectonics and exhumation of high-pressure metamorphic rocks in the Mediterranean orogens. Am. J. Sci. 303, 353-409.

Jolivet, L., Faccenna, C., Huet, B., Labrousse, L., Le Pourhiet, L., Lacombe, O., Lecomte, E., Burov, E., Denèle, Y., Brun, J.-P., Philippon, M., Paul, A., Salaün, G., Karabulut, H., Piromallo, C., Monié, P., Gueydan, F., Okay, A.I., Oberhänsli, R., Pourteau, A., Augier, R., Gadenne, L., Driussi, O., 2013. Aegean tectonics: strain localisation, slab tearing and trench retreat. Tectonophysics 597-598, 1-33. http://dx.doi.org/ 10.1016/j.tecto.2012.06.011.

Kadioglu, Y.K., Dilek, Y., 2010. Structure and geochemistry of the adakitic Horoz granitoid, Bolkar Mountains, south-central Turkey, and its tectonomagmatic evolution. Int. Geol. Rev. 52, 505-535. http://dx.doi.org/10.1080/ 09507110902954847.

Klaver, M., Davies, G.R., Vroon, P.Z., 2016. Subslab mantle of African provenance infiltrating the Aegean mantle wedge. Geology 44, 367-370.

Lefebvre, C., Barnhoorn, A., van Hinsbergen, D.J.J., Kaymakci, N., Vissers, R.L.M., 2011. Late Cretaceous extensional denudation along a marble detachment fault zone in the Kırşehir massif near Kaman, central Turkey. J. Struct. Geol. 33, 1220-1236. http://dx.doi.org/10.1016/j.jsg.2011.06.002.

Lefebvre, C., Meijers, M.J.M., Kaymakci, N., Peynircioğlu, A., Langereis, C.G., van Hinsbergen, D.J.J., 2013. Reconstructing the geometry of central Anatolia during the late Cretaceous: large-scale Cenozoic rotations and deformation between the Pontides and Taurides. Earth Planet. Sci. Lett. 366, 83-98. http://dx.doi.org/ 10.1016/j.epsl.2013.01.003.

Lister, G.S., Davis, G.A., 1989. The origin of metamorphic core complexes and detachment faults formed during Tertiary continental extension in the northern Colorado River region, USA. J. Struct. Geol. 11, 65-94.

Menant, A., Jolivet, L., Vrielynck, B., 2016. Kinematic reconstructions and magmatic evolution illuminating crustal and mantle dynamics of the eastern Mediterranean region since the late Cretaceous. Tectonophysics 675, 103-140.

MTA, 2002. Geological Map of Turkey, Scale 1:500,000. Mineral Research and Exploration Institute of Turkey.

Okay, A.I., 1986. High-pressure/low-temperature rocks of Turkey. In: Evans, B.W., Brown, E.H. (Eds.), Blueschists and Eclogites. Geological Society of America Memoir, pp. 333-347.

Okay, A.I., 1984. Distribution and characteristics of the north-west Turkish blueschists. Geol. Soc. (Lond.) Spec. Publ. 17, 455-466. http://dx.doi.org/10.1144/ GSL.SP.1984.017.01.33.

Özdamar, Ş., Billor, M.Z., Sunal, G., Esenli, F., Roden, M.F., 2013. First U-Pb SHRIMP zircon and ${ }^{40} \mathrm{Ar} /{ }^{39} \mathrm{Ar}$ ages of metarhyolites from the Afyon-Bolkardag Zone, SW Turkey: implications for the rifting and closure of the Neo-Tethys. Gondwana Res. 24, 377-391. http://dx.doi.org/10.1016/j.gr.2012.10.006.
Özgül, N., 1984. Stratigraphy and tectonic evolution of the Central Taurides. Geol. Taurus Belt, 77-90.

Parlak, O., Karaoğlan, F., Rizaoğlu, T., Klötzli, U., Koller, F., Billor, Z., 2013. U-Pb and ${ }^{40} \mathrm{Ar}-{ }^{39} \mathrm{Ar}$ geochronology of the ophiolites and granitoids from the Tauride belt: implications for the evolution of the Inner Tauride suture. J. Geodyn. 65, 22-37. http://dx.doi.org/10.1016/j.jog.2012.06.012.

Plunder, A., Agard, P., Chopin, C., Pourteau, A., Okay, A.I., 2015. Accretion, underplating and exhumation along a subduction interface: from subduction initiation to continental subduction (Tavsanlı zone, W. Turkey). Lithos 226, 233-254. http://dx.doi.org/10.1016/j.lithos.2015.01.007.

Poisson, A., Guezou, J.C., Ozturk, A., Inan, S., Temiz, H., Gürsöy, H., Kavak, K.S. Özden, S., 1996. Tectonic setting and evolution of the Sivas Basin, Central Anatolia, Turkey. Int. Geol. Rev. 38, 838-853. http://dx.doi.org/10.1080/ 00206819709465366

Pourteau, A., Bousquet, R., Vidal, O., Plunder, A., Duesterhoeft, E., Candan, O., Oberhänsli, R., 2014. Multistage growth of Fe-Mg-carpholite and Fe-Mg-chloritoid from field evidence to thermodynamic modelling. Contrib. Mineral. Petrol. 168, 1090. http://dx.doi.org/10.1007/s00410-014-1090-7.

Pourteau, A., Sudo, M., Candan, O., Lanari, P., Vidal, O., Oberhänsli, R., 2013. Neotethys closure history of Anatolia: insights from ${ }^{40} \mathrm{Ar}-{ }^{39} \mathrm{Ar}$ geochronology and P-T estimation in high-pressure metasedimentary rocks. J. Metamorph Geol. 31, 585-606. http://dx.doi.org/10.1111/jmg.12034.

Rosenbaum, G., Lister, G.S., 2004. Neogene and quaternary rollback evolution of the Tyrrhenian Sea, the Apennines, and the Sicilian Maghrebides. Tectonics 23.

Royden, L.H., 1993. Evolution of retreating subduction boundaries formed during continental collision. Tectonics 12, 629-638.

Schildgen, T.F., Cosentino, D., Caruso, A., Buchwaldt, R., Yıldırım, C., Bowring, S.a. Rojay, B., Echtler, H., Strecker, M.R., 2012. Surface expression of eastern Mediterranean slab dynamics: Neogene topographic and structural evolution of the southwest margin of the Central Anatolian Plateau, Turkey. Tectonics 31, TC2005. http://dx.doi.org/10.1029/2011TC003021.

Schmid, S.M., Panozzo, R., Bauer, S., 1987. Simple shear experiments on calcite rocks: rheology and microfabric. J. Struct. Geol. 9, 747-778

Seaton, N.C.A., Whitney, D.L., Teyssier, C., Toraman, E., Heizler, M.T., 2009. Recrystallization of high-pressure marble (Sivrihisar, Turkey). Tectonophysics 479, 241-253. http://dx.doi.org/10.1016/j.tecto.2009.08.015.

Simpson, C., Schmid, S.M., 1983. An evaluation of criteria to deduce the sense of movement in sheared rocks. Geol. Soc. Am. Bull. 94, 1281-1288.

Stipp, M., Stünitz, H., Heilbronner, R., Schmid, S.M., 2002. The eastern Tonale fault zone: a "natural laboratory" for crystal plastic deformation of quartz over a temperature range from 250 to $700^{\circ} \mathrm{C}$. J. Struct. Geol. 24, 1861-1884.

Tirel, C., Brun, J.-P., Burov, E., Wortel, M.J.R., Lebedev, S., 2013. A plate tectonics oddity: caterpillar-walk exhumation of subducted continental crust. Geology 41 555-558.

van Hinsbergen, D.J.J., Kaymakci, N., Spakman, W., Torsvik, T.H., 2010. Reconciling the geological history of western Turkey with plate circuits and mantle tomography. Earth Planet. Sci. Lett. 297, 674-686. http://dx.doi.org/10.1016/ j.epsl.2010.07.024.

van Hinsbergen, D.J.J., Maffione, M., Plunder, A., Kaymakci, N., Ganerød, M., Hendriks, B.W.H., Corfu, F., Gürer, D., Gelder, G.I.N.O., Peters, K., Others Hinsbergen, D.J.J. Maffione, M., Plunder, A., Kaymakci, N., Ganerød, M., Hendriks, B.W.H., Corfu, F. Gürer, D., Gelder, G.I.N.O., Peters, K., et al., 2016. Tectonic evolution and paleogeography of the Kırşehir Block and the Central Anatolian Ophiolites, Turkey. Tectonics 35, 983-1014

van Hinsbergen, D.J.J., Schmid, S.M., 2012. Map view restoration of Aegean-West Anatolian accretion and extension since the Eocene. Tectonics 31, TC5005 http://dx.doi.org/10.1029/2012TC003132.

Whitney, D.L., Hamilton, M.A., 2004. Timing of high-grade metamorphism in central Turkey and the assembly of Anatolia. J. Geol. Soc. Lond. 161, 823-828. 